Louisiana State University

LSU Digital Commons

Faculty Publications

Department of Oceanography \& Coastal

Sciences

3-1990

\title{
Estimation of Primary Production using Five Different Methods in a Spartina alterniflora Salt Marsh
}

Richardus F. Kaswadji

James G. Gosselink

R. Eugene Turner

euturne@lsu.edu

Follow this and additional works at: https://digitalcommons.Isu.edu/oceanography_coastal_pubs

\section{Recommended Citation}

Kaswadji, R. F., Gosselink, J. G., \& Turner, R. (1990). Estimation of Primary Production using Five Different Methods in a Spartina alterniflora Salt Marsh. Wetlands Ecology and Management, 1 (2), 57-64. Retrieved from https://digitalcommons.Isu.edu/oceanography_coastal_pubs/156

This Article is brought to you for free and open access by the Department of Oceanography \& Coastal Sciences at LSU Digital Commons. It has been accepted for inclusion in Faculty Publications by an authorized administrator of LSU Digital Commons. For more information, please contact ir@lsu.edu. 


\title{
Estimation of primary production using five different methods in a Spartina alterniflora salt marsh
}

\author{
Richardus F. Kaswadji, James G. Gosselink and R. Eugene Turner \\ Coastal Ecology Institute, Center for Wetland Resources, Louisiana State University, Baton Rouge, \\ LA 70803-7503, USA
}

Keywords: methodology, primary production, salt marsh, Spartina alterniflora

\begin{abstract}
The aboveground production of Spartina alterniflora in a salt marsh in Barataria Bay, Louisiana, USA was estimated using five different harvest methods: peak standing crop (PSC), Milner-Hughes, Smalley, WiegertEvans, and Lomnicki et al., and a non-destructive method based on measurement of stem density and longevity. Annual production estimates were $831 \pm 41,831 \pm 62,1231 \pm 252,1873 \pm 147$ and $1437 \pm 96 \mathrm{~g}$ dry wt $\mathrm{m}^{-2}$ for each method, respectively. The average longevity of individually tagged young shoots was $5.2 \pm 0.2$ months, equivalent to an annual turnover rate of 2.3 crops per year. Among the five methods, Wiegert-Evans and Lomnicki et al. were considered more accurate than the other three because they corrected for mortality losses between sampling times. The Lomnicki et al. method was preferred over the WiegertEvans method because of its greater simplicity.
\end{abstract}

\section{Introduction}

As the base of a complex food web, the production of Spartina alterniflora salt marshes has been of increasing interest. This has led ecologists to estimate the production of these systems using methods which vary from simple to complex. Reviews of primary production in $S$. alterniflora dominated salt marshes by Keefe (1972), Turner (1976), Kirby and Gosselink (1976), Hopkinson et al. (1978), and Linthurst and Reimold (1978) show a wide range of production, the estimates depending partially on the choice of method. All but one field comparison of methods used to estimate production are from marshes along the Atlantic coast. Shew et al. (1981), the most complete study to date, compared five methods of estimating production from a single data set in a $S$. alterniflora salt marsh in southeastern North Carolina. Their results may not be directly applicable to the Gulf marshes because of the different seasonality, temperature, tidal regime, geology, and plant turnover rate.

In this Gulf of Mexico marsh study, we used the same five harvest methods as Shew et al. (1981) to compare production estimates: (1) peak standing crop (PSC); (2) Milner-Hughes (1968); (3) Smalley (1958); (4) Wiegert-Evans (1964); and (5) Lomnicki et al. (1968). A non-destructive estimate was also made from culm longevity and mean live culm biomass. Kirby and Gosselink (1976) conducted a similar study at Barataria Bay, Louisiana using all the methods except the Lomnicki et al. Hopkinson et al. (1978) studied a nearby area using only the PSC and Wiegert-Evans methods.

The objectives of this study were to compare the five methods of production estimation and to estimate annual plant turnover rate at the study area. We hypothesized (1) that techniques correcting for 


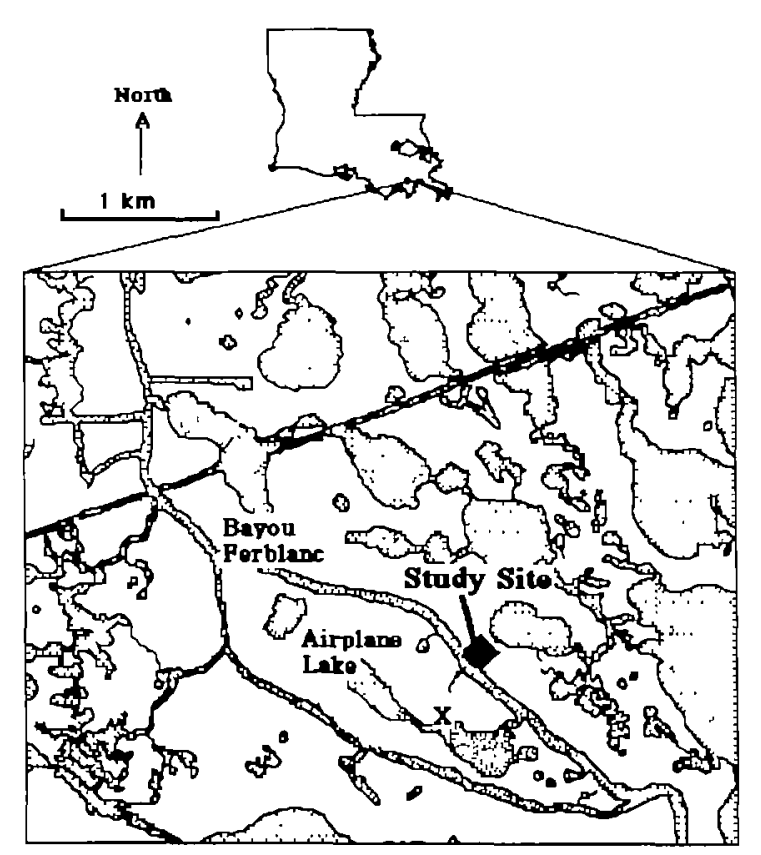

Fig. 1. Location of Airplane Lake, showing the sampling sites for this study (black square) and Hopkinson et al. (X).

mortality losses between harvests would give higher estimates of production than techniques that do not correct for these losses; and (2) that the differences among techniques would be larger in Gulf of Mexico than east coast sites because of the longer season, warmer winter, and hence larger turnover rate.

\section{Materials and methods}

We studied a Spartina alterniflora-dominated area located along Bayou Ferblanc, within $0.5 \mathrm{~km}$ of Airplane Lake in Barataria Bay, Louisiana (Fig. 1). About 95 to $99 \%$ of vegetation was $S$. alterniflora and the remainder was $S$. patens.

We sampled the aboveground S. alterniflora biomass every month from May 1980 to June 1981. On each sampling date, ten replicates were cut about 20 $\mathrm{m}$ apart, on a transect perpendicular to the bayou (Fig. 2). Although we recognized the possibility of a productivity gradient along the bayou, we chose this design in preference to a more random design because the latter would have required frequent access to the whole sampling site. In earlier studies (Kirby and Gosselink 1976; Hopkinson et al. 1978)

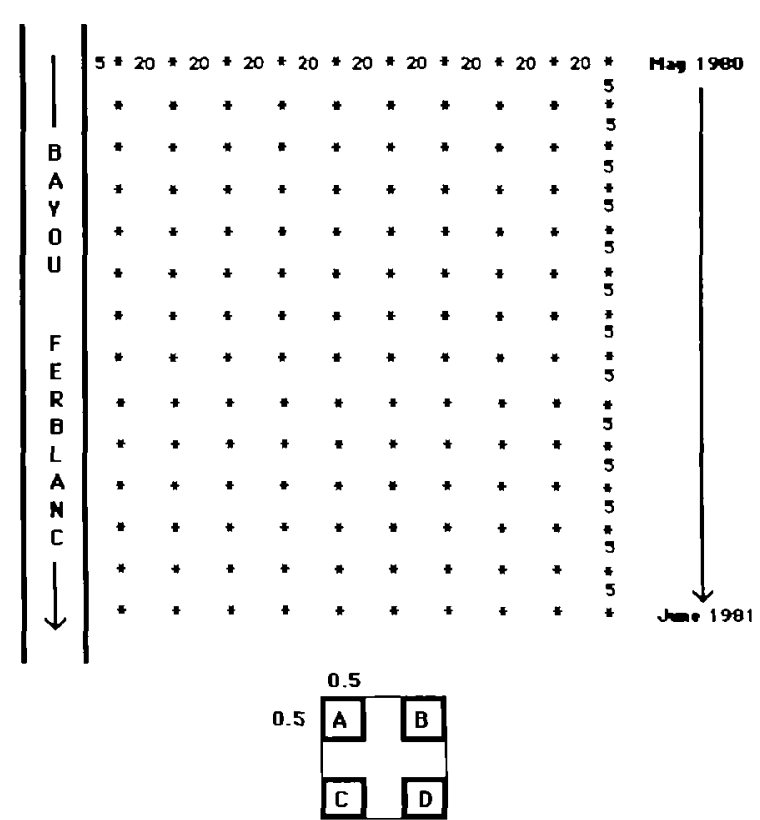

Fig. 2. Monthly sampling transects along Bayou Ferblanc. The asterisk $\left(^{*}\right)$ is the sampling site location. The distance between locations was $20 \mathrm{~m}$ along the transect and $5 \mathrm{~m}$ south (down) the next month. The square at the bottom is the sampling design for each location. A, B, C, and D were randomly determined; dimensions are in meters.

we found severe disturbance, including death of vegetation, along paths between plots. The sampling site was visually homogeneous along the bayou. Each replicate was divided into four $0.25 \mathrm{~m}^{2}$ quadrat-plots (A, B, C, and D) with a space of 0.5-1.0 m between plots. Plots $A, B, C$, and D were determined randomly, and sampled as described by Shew et al. (1981). On each sampling trip we removed from plot $A$ all standing live and dead culms and litter, from plot $B$ the live culms without disturbing the dead material, and from plot $C$ dead culms and litter without disturbing the live material. Nothing was removed from plot D until harvest, one month later. Plot $C$ and $D$ were enclosed with $3 \mathrm{~mm}$ mesh hardware cloth screen wire cages $\left(0.5 \times 0.5 \mathrm{~m}^{2}\right.$ by $90 \mathrm{~cm}$ high) to reduce the lateral exchange of detritus that might increase the variability of dead biomass in the plots. On the next sampling trip, the dead culms and litter in plot $B$, and the live and dead culms and litter in plots $C$ and $D$ were harvested. Then a new set of A, B, C, and D plots was set up about $5 \mathrm{~m}$ downstream from the old ones. 


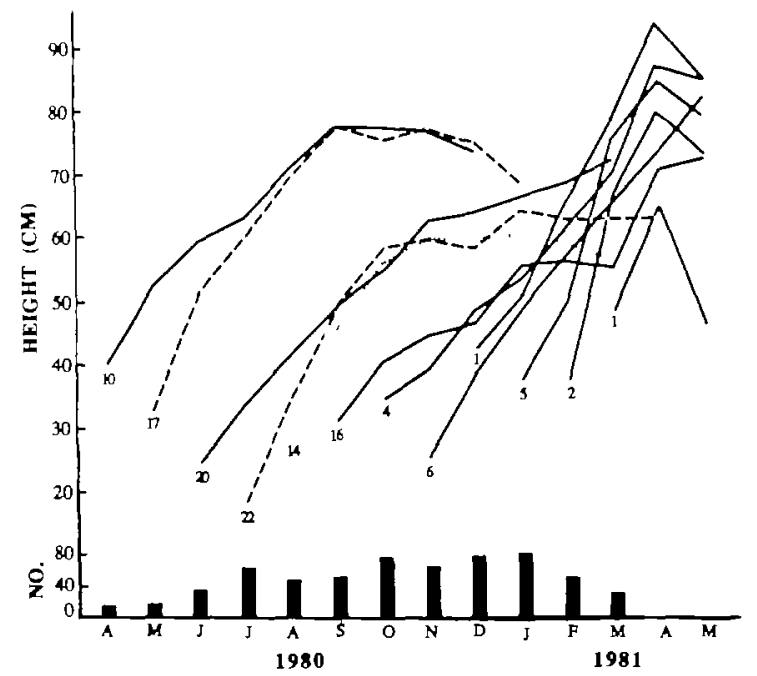

Fig. 3. Average height of culms tagged each month; curves end when the last culm is dead; number of culms initially tagged is beneath each line; solid, dashed, and dotted lines are used to distinguish different cohorts. Bar graphs are the numbers of culms $<25 \mathrm{~cm}$ tall per $\mathrm{m}^{2}$.

We placed the plant material removed from each plot in plastic bags and, in the laboratory, separated material into live culms, dead culms plus litter, and dead parts that were removed from the live culms. Plant material was dried at $60^{\circ} \mathrm{C}$ to constant weight to the nearest $0.1 \mathrm{~g}$.

We also tagged small live culms to determine their longevity and turnover rate. Twenty-five new culms of $S$. alterniflora were marked each month, and each was measured monthly to the tip of the tallest leaf until it was found dead. The culm turnover rate was calculated using the following equations:

Turnover rate $=\frac{\text { Length of growing season (days) }}{\text { Average longevity (days) }}$

Average longevity $=$

$$
\frac{\left.\sum_{c=1}^{n} \text { (longevity (days) } \times \text { density of stems }\left(\# m^{-2}\right)\right)}{\sum_{c=1}^{n}\left(\text { density of stems }\left(\# \mathrm{~m}^{-2}\right)\right)}
$$

where the growing season for S. alterniflora at the study area was 365 days, $c=$ cohort, and $n=$ months.
Table 1 . Average density and longevity of S. alterniflora culms, and number of culms used to determine average longevity each month (1980-1981); 25 culms were tagged each month.

\begin{tabular}{llll}
$\begin{array}{l}\text { Month } \\
\text { of tagging }\end{array}$ & $\begin{array}{l}\text { Average density } \\
\text { of culms less than } \\
25 \mathrm{~cm}\left(\# \text { per } \mathrm{m}^{2} \text { ) }\right.\end{array}$ & $\begin{array}{l}\text { Average } \\
\text { longevity } \\
\text { (days) }\end{array}$ & $\begin{array}{l}\text { No. culms to } \\
\text { determine } \\
\text { avg. longevity }\end{array}$ \\
\hline 4 & 14.8 & 169 & 10 \\
5 & 16.6 & 130 & 17 \\
6 & 34.8 & 190 & 20 \\
7 & 64.8 & 133 & 22 \\
8 & 46.8 & 186 & 14 \\
9 & 54.4 & 163 & 16 \\
10 & 76.0 & 171 & 4 \\
11 & 64.0 & 143 & 6 \\
12 & 77.6 & 102 & 1 \\
1 & 79.6 & 117 & 5 \\
2 & 52.4 & 97 & 2 \\
3 & 31.0 & 63 & 1 \\
\hline
\end{tabular}

\section{Results}

\section{Culm longevity and seasonal standing crops}

Culms tagged in winter (December through March) had higher growth rates than culms tagged in other months (Fig. 3). The winter-tagged culms also appeared to live a shorter period (Table 1), but this conclusion is somewhat in question since the sample number in winter months was small. Based on the life spans of 118 individual culms, the average longevity (mean \pm 1 std. error) of $S$. alterniflora culms at the study area was $5.2 \pm 0.2$ months (160 days) or 2.3 crops per year. This life span is shorter than those obtained by Shew et al. (1981) for S. alterniflora in a southeastern North Carolina salt marsh, which were $8.0 \pm 0.4,7.6 \pm$ 0.4 , and $8.1 \pm 0.6$ months for short, medium, and tall S. alterniflora, respectively. The culm longevity in this study was also less than estimated by Hopkinson et al. (1980), which was 7.4 months (222 days).

Live standing crop averaged $415 \mathrm{~g}$ dry wt $\mathrm{m}^{-2}$ and ranged from $62 \mathrm{~g} \mathrm{~m}^{-2}$ in February-March, to $831 \mathrm{~g} \mathrm{~m}^{-2}$ in July-August (Fig. 4). The total amount of dead material, consisting of the dead standing culms, litter, and the dead parts that were attached to the live culms, averaged $885 \mathrm{~g}$ dry wt 

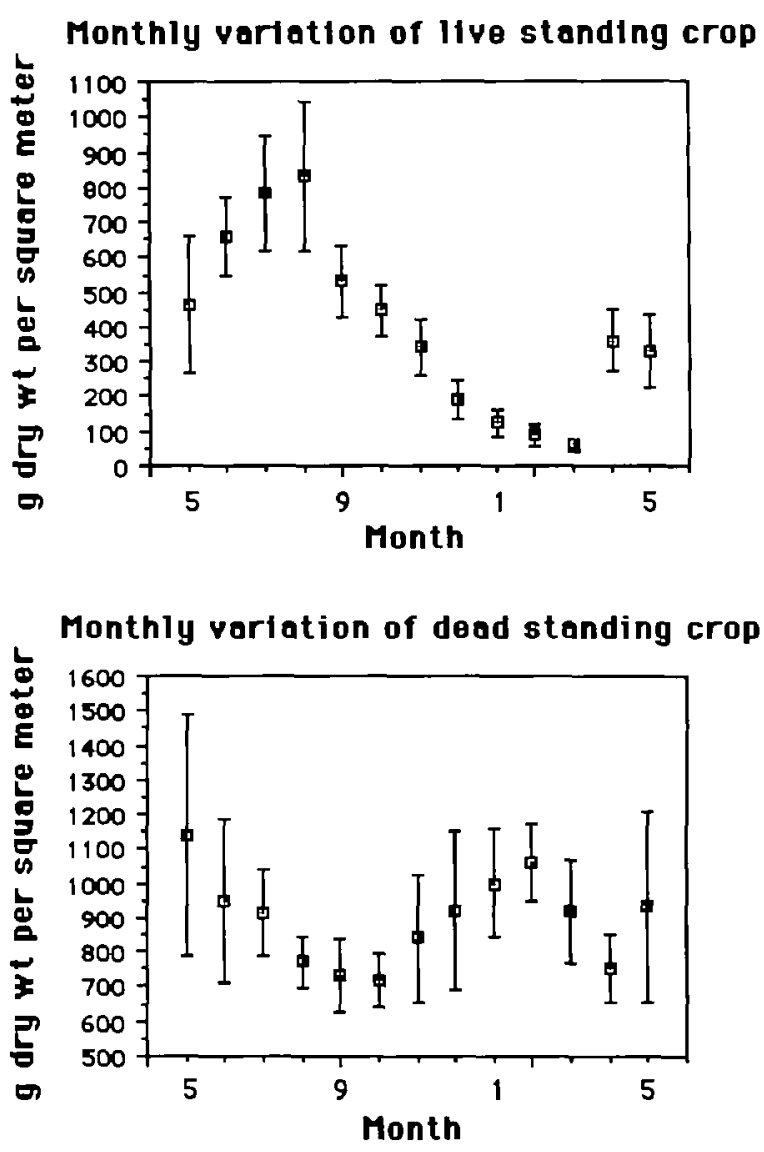

Fig. 4. Monthly variation of live and dead standing crop; the bars are standard deviations; the dead material includes litter and dead parts removed from live culms.

$\mathrm{m}^{-2}$ and ranged from 718 to $1138 \mathrm{~g}$ dry $w t \mathrm{~m}^{-2}$. The lowest value for dead material was recorded in September-October, and the highest value was, as expected, in January-February when live material was lowest.

There was no effect of screening on live or dead biomass. The removal of dead material from plot $\mathrm{C}$ at the beginning of each sampling seemed to reduce the standing stock of live material; after one month the live biomass in plot $\mathrm{C}$ was smaller than in plots $A$ and $D$. Further, the removal of live material from plot $B$ at the beginning of each sampling reduced the amount of dead material at the end of each sampling by about $18 \%$.

When all samples were treated together, there was no detectable effect of distance along the transect from the Bayou Ferblanc on the amount of live and dead material. However, the highest dry weights were recorded at Replicate 1 next to the Bayou and Replicate 10 , close to a relatively large body of water.

\section{Production estimates}

There was no difference in the amount of either live or dead material in plots A compared to D. Thus, we used the average values of A-dead and D-dead for Dead, and the average values of A-live and Dlive for Live, in calculating production. When only A-live or D-live, and A-dead or D-dead was available, we used the mean of the available values. Otherwise, we used mean values of the ten replicates in the calculations (see Kaswadji 1982 or Shew et al. 1981 for a detailed description of each method).

We estimated the production of each of the 10 replicates and averaged them into mean production (mean \pm 1 std. error). The estimates ranged from $831 \pm 41 \mathrm{~g}$ dry wt $\mathrm{m}^{-2} \cdot \mathrm{yr}^{-1}$ using PSC to $1873 \pm$ $147 \mathrm{~g}$ dry wt $\mathrm{m}^{-2} \cdot \mathrm{yr}^{-1}$ using the Wiegert-Evans method (Table 2). These estimates are higher than those Shew et al. (1981) obtained (241 to $1029 \mathrm{~g}$ dry wt $\mathrm{m}^{-2} \cdot \mathrm{yr}^{-1}$ ) using the same method for a southeastern North Carolina S. alterniflora salt marsh. The difference agrees with the observations that salt marsh production is higher at lower latitudes (Turner 1976).

Monthly production estimates for the four methods indicate generally that production was relatively high in June, when the study started, then decreased to a minimum in September (Fig. 5). After that, the monthly estimates varied depending on method. The Milner-Hughes method simply measures the sum of all monthly positive live biomass increases. The results from this method indicate no production from September through March, a rapid increase the next month, and then a decrease in May. Months of no production are, of course, unrealistic because growth was observed in the tagging studies (Fig. 3).

The Smalley method corrects for mortality between samples by summing algebraically the change in live biomass and in dead biomass (negative totals are set to zero). Results using the Smalley method 
Table 2. Summary of annual primary production and turnover rates for Spartina alterniflora; numbers in parentheses are the results if 'negative production' is counted as zero.

\begin{tabular}{|c|c|c|c|c|c|c|}
\hline \multirow[t]{2}{*}{ Methods } & \multicolumn{4}{|c|}{ Primary production ( $\mathrm{g}$ dry $w \mathrm{wt}^{-2} \cdot \mathrm{yr}^{-1}$ ) } & \multirow{2}{*}{$\begin{array}{l}\text { Annual turnover rate } \\
\text { (production to peak } \\
\text { standing crop) for } \\
\text { this study }\end{array}$} & \multirow{2}{*}{$\begin{array}{l}\text { Amount under }(-) \text { or } \\
\text { over }(+) \text { estimate of } \\
\text { turnover rate relative to } \\
\text { calculated turnover rate } \\
(2.3) \text { for this study }\end{array}$} \\
\hline & This study 1 & $\begin{array}{l}\text { Kirby and } \\
\text { Gosselink } \\
(1976)^{2}\end{array}$ & $\begin{array}{l}\text { Hopkinson } \\
\text { et al. } \\
(1978)^{3}\end{array}$ & $\begin{array}{l}\text { Shew et al. } \\
(1981)^{4}\end{array}$ & & \\
\hline $\begin{array}{l}\text { Peak standing } \\
\quad \text { стор }\end{array}$ & $831 \pm 41$ & 903 & 754 & 242 & 1.0 & -1.3 \\
\hline Milner-Hughes & $831 \pm 62$ & 811 & - & 241 & 1.0 & -1.3 \\
\hline Smalley & $1231 \pm 252$ & 1200 & - & 225 & 1.5 & -0.8 \\
\hline Wiegert-Evans & $\begin{array}{l}1873 \pm 147 \\
(2733 \pm 235)\end{array}$ & 1988 & 2658 & $\begin{array}{l}1029 \\
(1038)\end{array}$ & $\begin{array}{c}2.2 \\
(3.3)\end{array}$ & $\begin{array}{l}-0.1 \\
(+1.0)\end{array}$ \\
\hline Lomnicki et al. & $\begin{array}{l}1437 \pm 96 \\
(2046 \pm 125)\end{array}$ & - & - & 1028 & $\begin{array}{c}1.7 \\
(2.5)\end{array}$ & $\begin{array}{l}-0.6 \\
(+0.2)\end{array}$ \\
\hline
\end{tabular}

'Transect across a mostly inland site.

${ }^{2}$ Average of streamside and inland sites.

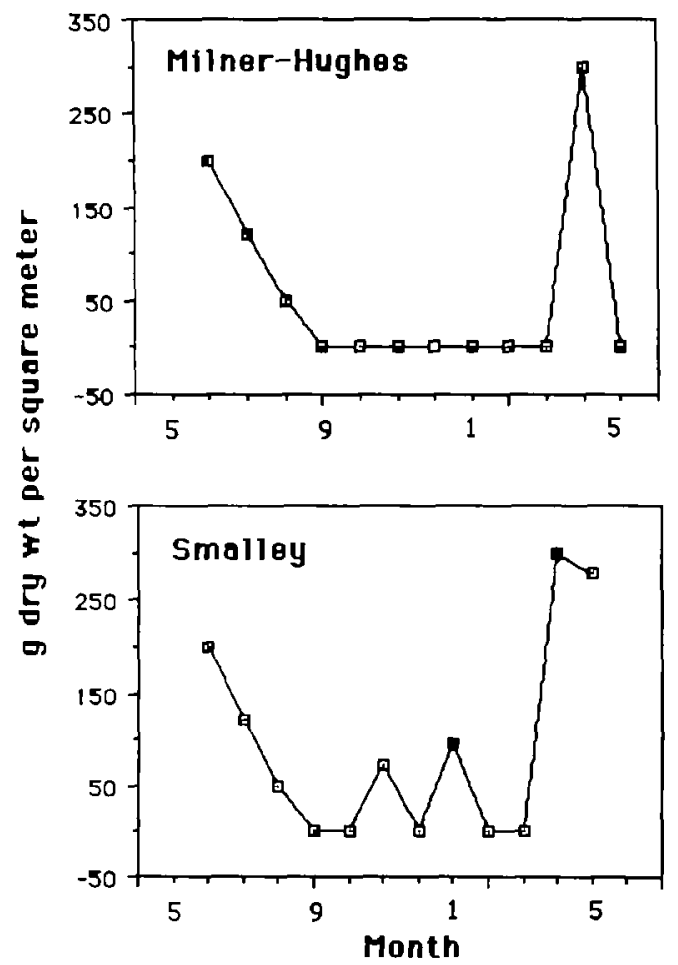

${ }^{3}$ Intermediate streamside to inland marsh site. ${ }^{4}$ Short marsh.
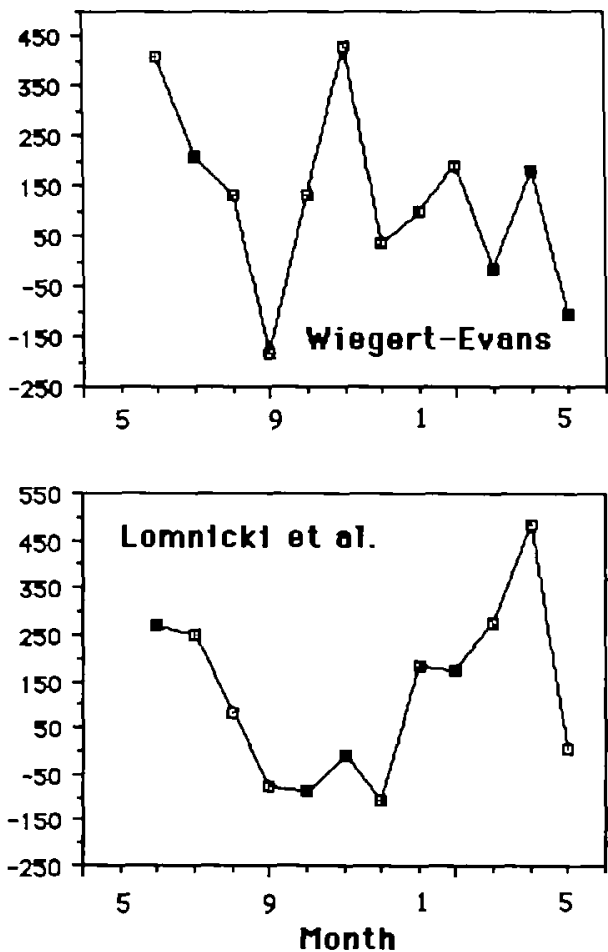

Fig. 5. Estimates of monthly production using the four different methods.

were similar to Milner-Hughes, with peak production in May, June, and July and low, variable production from September through March.

The Wiegert-Evans method calculates loss of dead material each month (from B plots), and adds that to the change in dead standing stock $(A+D$ plots) to estimate mortality. Mortality, in turn is added to the change in live biomass (from $\mathrm{A}+\mathrm{D}$ plots), to estimate production. Variability is generally high, and negative values can occur, pre- 
sumably due to random variation. In order not to bias the results upward, these values were retained in the annual estimate. The Wiegert-Evans method estimated negative production in September, March, and May, with considerable month-tomonth variation. The high production calculated in November contrasted with the other methods.

In the Lomnicki et al. method, mortality is estimated directly by the appearance of dead plant material one month after removal of all dead culms from C plots. As with the Wiegert-Evans method, monthly mortality is added to the change in live biomass to estimate production. The monthly production rates from the Lomnicki et al. method were negative from September through December. They were highest in April through July, with the exception of May. Negative net production does not occur, by definition. In this technique if no production occurs during a month, any mortality (loss of live biomass) should appear as dead biomass accumulation. Negative values represent both loss of dead biomass from $C$ plots during the interval between samples and statistical variation among plots. Because setting negative values to zero may bias the production estimate upward, we retained those values.

\section{Discussion}

\section{Production estimates}

Peak standing crop method. The mean live standing crop for the month (August) when standing crop peaked in most plots, was $831 \pm 41 \mathrm{~g}$ dry wt $\mathrm{m}^{-2} \cdot \mathrm{yr}^{-1}$, which is comparable with results of both Hopkinson et al. $\left(1978 ; 754 \mathrm{~g} \mathrm{~m}^{-2} \cdot \mathrm{yr}^{-1}\right)$, and Kirby and Gosselink (1976; $\left.903 \mathrm{gm}^{-2} \cdot \mathrm{yr}^{-1}\right)$. This method does not consider either production of live material after the seasonal peak, or the effects of mortality occurring between sampling events. Thus, this method usually underestimates true production, especially in low latitudes (Turner 1976).

Milner-Hughes method. Production estimated by this method was $831 \pm 62 \mathrm{~g}$ dry wt $\mathrm{m}^{-2} \cdot \mathrm{yr}^{-1}$, or about the same as the production estimated from PSC. Using the Milner-Hughes method, Kirby and Gosselink (1976) obtained $811 \mathrm{~g}$ dry wt $\mathrm{m}^{-2} \cdot \mathrm{yr}^{-1}$ production for $S$. alterniflora in Airplane Lake, Louisiana. Since this method, like the previous one, does not account for mortality between sampling periods, it also underestimates production.

Smalley method. Production estimated using this method was $1231 \pm 252 \mathrm{~g}$ dry wt m $\mathrm{m}^{-2} \cdot \mathrm{yr}^{-1}$. Kirby and Gosselink (1976), using the same method at Airplane Lake, recorded $1200 \mathrm{~g}$ dry wt $\mathrm{m}^{-2} \cdot \mathrm{yr}^{-1}$ production for S. alterniflora. Turner (1976) noted that when live biomass is increasing between sampling periods, a possible underestimate of production one month may be corrected by an overestimate in the following months. But when live biomass is decreasing, the errors in the estimate of the actual production cannot be corrected. Smalley (1958) wrote that even if there were no statistical variations, the method would still underestimate production at times. Thus, although the calculation of production using this method is higher than the previous two methods, it also underestimates the actual production rate.

Wiegert-Evans method. This production estimate was $1873 \pm 147 \mathrm{~g}$ dry wt $\mathrm{m}^{-2} \cdot \mathrm{yr}^{-1}$. This method does not treat negative monthly values as zero as does the Smalley method, but treats them as 'negative production' in totaling annual production. 'Negative production' is assumed to be a statistical artifact resulting from the large error terms of the method of calculation. In the calculations, we included dead parts attached to the live culms as dead material. In one modification of the method that excluded the dead parts of live culms from the total dead material, Shew et al. (1981) found a $33.7 \%$ reduction of production. They concluded that if this dead material is excluded from the calculation, actual production is biased toward underestimation. Hopkinson et al. (1978) noted that in Louisiana, the production estimated using the Wiegert-Evans method is 2 to 4.4 times greater than peak standing biomass. The method is probably more accurate than the previous methods, because it corrects for mortality occurring between sampling periods, through consideration of the instantaneous rate of disappearance of dead material and changes in dead biomass between sampling times.

Lomnicki et al. method. Production estimated 
using this method was $1437 \pm 96 \mathrm{~g}$ dry wt $\mathrm{m}^{-2} \cdot \mathrm{yr}^{-1}$. This method used the dead material from plot $\mathrm{C}$ to estimate mortality between sampling times. There are no other studies of this method in Louisiana S. alterniflora stands for comparison. Compared to other harvest-based estimates, true net production should be represented best by the Lomnicki et al. method, because it is the most direct measurement of both biomass change and mortality. None of these methods correct for herbivory, which has been reported to be negligible in salt marshes (Smalley 1958).

\section{Turnover rate}

The culm turnover rate of $S$. alterniflora at the study area was 2.3 crops per year. Hopkinson et al. (1980) measured 2.9 crops per year in another Louisiana salt marsh. These two estimates were higher than the measured turnover rate of 1.5 for $S$. alterniflora in southeastern North Carolina (Shew et al. 1981).

We also calculated turnover rates using the ratio of annual primary production and standing crop (Table 2). Because the culms die after reaching their peak sizes, not their mean sizes, we used the peak live standing crop, not the mean live standing crop, in this calculation. Turnover rates based on the ratio of Lomnicki production to PSC and of WiegertEvans production to PSC were 1.7 and 2.2, slightly lower than the turnover rate calculated from stem tagging. Thus, based on the comparison of turnover rates, all estimates of primary production in this study were underestimates of actual production.

The tagging study shows that production was actually occurring during the winter (and that the negative values are therefore unrealistic). All stems tagged in late summer were growing during the fallwinter period; their growth rates were relatively high, and stem density in September through January was higher than the average monthly mean (Fig. $3)$. One possible source of error was the effect of clipping material from $\mathrm{C}$ and $\mathrm{D}$ plots, which may have influenced mortality and growth rates in undetermined ways.
Primary production rates in Louisiana marshes are up to two times higher than PSC, primarily because of the rapid turnover of plant biomass. The Wiegert-Evans and Lomnicki et al. methods provide the most accurate procedures for measuring plant production of the five methods examined, but data collection is labor intensive. Harvest measurement of PSC combined with non-destructive estimation of culm turnover rate is a less laborious method of estimating net primary production, that gives results comparable to Wiegert-Evans and Lomnicki et al. All three methods require repetitive sampling, on a maximum interval of four weeks, for reproducible results. Considerable savings in time and effort would result if turnover rates for a species could be reliably related to latitude.

The difference between the minimum and maximum estimates using the five methods was $787 \mathrm{~g}$ $\mathrm{m}^{-2}$ in North Carolina (Shew et al. 1981) and 1052 $\mathrm{g} \mathrm{m}^{-2}$ in Louisiana (this study). The ratio of Wiegert-Evans production to PSC was 4.2 in North Carolina (Shew et al. 1981) but 2.2 in this study. A comparison of these turnover rates suggests that turnover rate increases with latitude, contrary to earlier views (Turner 1976). Since production estimates from PSC times turnover rate are sensitive to small changes in turnover rate, the wide range found in these studies argues against use of turnover rate for estimating production. We require more extensive data on turnover rates before they can be widely applied for estimating production.

\section{Acknowledgments}

This research was funded by MUCIA/AID, the Louisiana Offshore Oil Port, Inc., and The Louisiana Sea Grant Program. The authors thank Dr. James Geaghan for helping in the data analysis.

\section{References}

Hopkinson, C.S., Gosselink, J.G. and Parrondo, R.T. 1978. Aboveground production of seven marsh plant species in coastal Louisiana. Ecology 59: 760-769.

Hopkinson, C.S., Gosselink, J.G. and Parrondo, R.T. 1980. Production of coastal Louisiana marsh plants calculated from 
phenometric techniques. Ecology 61: 1091-1098.

Kaswadji, R.F. 1982. The estimation of primary production using five different methods in a Spartina alterniflora salt marsh in Barataria Bay, Louisiana. M.Sc. Thesis, Dept. Marine Sciences, Louisiana State University, Baton Rouge, LA. USA 40 pp.

Keefe, C.W. 1972. Marsh production: a summary of the literature. Contr. Mar. Sci., 16: 164-181.

Kirby, C.J. and Gosselink, J.G. 1976. Primary production in a Louisiana gulf coast Spartina alterniflora marsh. Ecology 57: 1052-1059.

Linthurst, R.A. and Reimold, R.J. 1978. An evaluation of methods for estimating the net aerial primary productivity of estuarine angiosperms. J. Appl. Ecol. 15: 919-931.

Lomnicki, A., Bandola, E. and Jankowaska, K. 1968. Modification of the Wiegert-Evans method for estimation of net primary production. Ecology 49: 147-149.
Milner, C. and Hughes, R.E. 1968. Method for the measurement of the primary production of grasslands. IBP Handbook No. 6, Blackwell Scientific Publ., Oxford, England. 70 pp.

Shew, D.M., Linthurst, R.A. and Seneca, E.D. 1981. Comparison of production computation methods in a southeastern North Carolina Spartina alterniflora salt marsh. Estuaries 4: 97-109.

Smalley, A.E. 1958. The role of two invertebrate populations, Littorina irrorata and Orchelium fidicinium, in the energy flow of a salt marsh ecosystem. Ph.D. Dissertation, Univ. of Georgia, Athens, GA. USA.

Turner, R.E. 1976. Geographic variation in salt marsh macrophytic production: a review. Contr. Mar. Sci. 20: 47-68.

Wiegert, R.G. and Evans, F.C. 1964. Primary production and the disappearance of dead vegetation in an old field in Southwestern Michigan. Ecology 45: 49-63. 